\title{
The Onto-epistemology of Big Data
}

\author{
Roy Alfaro Vargas ${ }^{1}$ \\ https://orcid.org/0000-0001-5893-2415
}

\begin{abstract}
This study puts forward the results of a comprehensive literature review that allows of the exploration of the big data phenomenon as in technical terms as well in socio-political and philosophical ones, through the reading of authors such as Rob Kitchin (2014), Dawn E. Holmes (2017), and so forth. It is here offered a new critical approach to Big Data as long as the analysis have permitted us to evaluate not only the components of this new data science, but also the onto-epistemological consequences derived from the development and implementation of Big Data as in the scientific field as well in the quotidian. Also, this paper permits us to understand the linkage between Big Data and set theory in the construction of an onto-epistemology related to a political conservatism so that we are able to have the complete panorama in order to elaborate, in the near future, strategies to sublate such a phenomenon.
\end{abstract}

Keywords: Latin American Marxist Studies, Neoliberalism, Set Theory, Algorithms, Capitalism.

\section{A onto-epistemologia do Big Data \\ RESUMO}

Este estudo apresenta os resultados de uma pesquisa bibliográfica, que permite a exploração do fenômeno do Big Data, tanto em termos técnicos, quanto em termos sociopolíticos e filosóficos, através da leitura de autores como: Rob Kitchin (2014), Dawn E. Holmes (2017), entre outros. Aqui, uma nova abordagem crítica para o Big Data é oferecida, pois a análise nos permitiu avaliar não apenas os componentes desta nova ciência de dados, mas também as consequências onto-epistemológicas decorrentes do desenvolvimento e implementação do Big Data, tanto no campo científico e no cotidiano. Além disso, este artigo nos permite entender a ligação entre Big Data e definir a teoria na construção de uma epistemologia ligada ao conservadorismo político, para que possamos ter um quadro completo para desenvolver, no futuro estratégias para superar tal fenômeno.

Palavras chave: Estudos Latinoamericanos Marxistas, Neoliberalismo, Teoria de Conjuntos, Algorítmos, Capitalismo.

\section{La onto-epistemología del Big Data \\ RESUMEN}

Este estudio presenta los resultados de una investigación bibliográfica, la cual permite la exploración del fenómeno del Big Data tanto en términos técnicos, como también en términos socio-políticos y filosóficos, a través de la lectura de autores como: Rob Kitchin (2014), Dawn E. Holmes (2017), etc. Aquí se ofrece una nueva aproximación crítica al Big Data, en la medida que el análisis nos ha permitido evaluar no solo los componentes de esta nueva ciencia de datos, sino también las consecuencias onto-epistemológicas derivadas del desarrollo e implementación del Big Data tanto en el campo científico, como en lo cotidiano. También, este artículo nos permite comprender el vínculo entre el Big Data y la teoría de conjuntos en la construcción de una onto-epistemología ligada a un conservadurismo político, con el fin de que nosotros podamos tener un panorama completo para elaborar, en el futuro cercano, estrategias para superar tal fenómeno.

Palabras clave: Estudios latinoamericanos marxistas, neoliberalismo, teoría de conjuntos, algoritmos, capitalismo.

\section{Introduction}

To Alejandra

Our lives are now marked by the development of information technologies, which invade our everyday life with cell-phones, tablets, smart TVs, and so forth. Such apparatuses apparently promote the sociability among us, but really demote our capacity of thinking.

\footnotetext{
${ }^{1}$ Independent Researcher, Costa Rica. Email: rovalfarov@yandex.com
} 
Constantly, we are producing data for anyone is able to pay for them. Our lives are being recorded and we are being profiled so long as our everyday life has been captured by the interests, hidden behind the algorithms of Big Data, of the bourgeoisie. ${ }^{2}$

In this sense, our thesis is the following: Big Data is both a mechanism of social control and a tool for enhancing the circulation/reproduction of capital -Big Data is a neoliberal policy.

To prove such a thesis, we shall require Big Data to be defined, as well as to determine the sociopolitical outcome stemmed from the application of big data policies in order to finally establish the relationship between Big Data and set theory.

Methodologically, this investigation is based upon a comprehensive literature review that admits of the exploration of the subject in technological terms, just as in socio-political ones. This approach permits both defining the fundamental topics of Big Data as a technical process and, in tandem, critically understanding the socio-political consequences derived from the utilization of such techniques. Also, the study allows us to relate the big data phenomenon to the development of the onto-epistemology of set theory.

\section{The concept of Big Data}

Big Data may be defined in two distinct ways. Firstly, on the one hand, we shall understand the big data phenomenon in technical terms; that is, as a set of techniques (velocity, volume, etc.) that permits processing large quantities of data. Secondly, on the other hand, we can comprehend Big Data as a neoliberal policy, viz., as a unified and contextualized phenomenon.

In the first way, Big Data are made up of a group of essential features, which, as an ensemble, permits the processing of a great amount of data. Among such features, we can find notions such as: velocity, volume, variety (Kitchin, 2014, Shu, 2016; Holmes, 2017), and veracity (Shu, 2016; Holmes, 2017), just as resolution, indexicality, relationality, flexibility, extensionality, scaleability (Kitchin, 2014), and exhaustivity (Kitchin, 2014; Kitchin and McArdle, 2016). In this context, Kitchin and McArdle assumes velocity and exhaustivity to be "the key characteristics of Big Data" $(2016,8)$ insofar as velocity allows processing data in real time, while exhaustivity tends to provide validity.

Furthermore, the operationalization of such techniques is achieved by the use of algorithms, to wit: "a computational formula that autonomously makes decisions based on statistical models or decision rules without explicit human interaction" (Lee, 2018, 3). In other words, an algorithm is the mathematization of a process understood in terms of an if-then mechanism, which allows of the management of the flow of data and its processing.

Thus, the implementation of such techniques and algorithms permits processing structured data, semi-structured data, and unstructured data (Holmes, 2017; Aragona and de Rosa, 2018). In this manner, we have to comprehend the difference among all these kinds of data. On the one hand, "Structured data (...) is now stored electronically on spreadsheets or databases, and consists of spreadsheet-style tables with rows and columns, each row being a record and each column a welldefined field (e.g. name, address, and age)" (Holmes, 2017). That means, structured data corresponds to the data that have generally been supplied ${ }^{3}$

by the user itself in the process of affiliation to some website or social networking sites.

On the other hand, "unstructured data is not so easily categorized and includes photos, videos, tweets, and word-processing documents" (Holmes, 2017). These data belong to all sort of data "produced" by the user that does not respond to a well-defined field. As examples of this type of data, we can point out the data generated through "Web pages, satellite images, and surveillance videos" (Aragona and de Rosa, 2018, 3).

\footnotetext{
2 Put another way, Couldry and Mejias say, "everyday life will have become directly incorporated into the capitalist process of production" (2018, 8). ${ }^{3}$ For instance, "incomprehensible documents called Terms of Service, which contain outlandish appropriative claims by corporations" (Couldry and Mejias, 2018, 6).
} 
Additionally, semi-structured data must be understood as the data that involve "Narratives, texts, and images" (Aragona and de Rosa, 2018). This type of data implies some degree of structuration as long as these data are "included by the user" (Aragona and de Rosa, 2018, 3) -a particular user. Nonetheless, the combination of texts (natural languages) and images complicates such data processing, since it is so difficult to process the emotional content that pervades this sort of communication, just as the pragmatic uses of languages.

Also, to process these distinct data, it is necessary to utilize different platforms of processing. For instance, to store and manage structured data, "a relational database management system (RDBMS) is used" (Holmes, 2017) in order to enable us to analyze such data with SQL (structured data language) (Holmes, 2017). In contrast to structured data, unstructured data is managed by, for example, Hadoop that is a distributed file system (DFS) (Holmes, 2017). On the other hand, semi-structured data is processed by "The eXtensible Markup Language (XML) [that] allows semistructured data to be marked-up into a corpus in order to retrieve their meaning" (Aragona and de Rosa, 2018, 3). In sum, the implementation of SQL, XML, and Hadoop permits Big Data to manage all class of data, with which it is enhanced the efficiency of such data processing.

At this point, it is worth mentioning that the success of Big Data lies in the capacity of processing a large quantity of data, with velocities that today reach measurements such as Exabytes ${ }^{4}$

or Zettabytes (Xu and Duan, 2018). Thus, the more amount of data is gathered in less time, the more exactitude in statistical terms is reached by big data analytics.

Now, we are able to give a technical definition of the big data phenomenon:

'Big data' is now used to refer not just to the total amount of data generated and stored electronically, but also to specific datasets that are large in both size and complexity, with which new algorithmic techniques are required in order to extract useful information from them (Holmes, 2017).

So far we have described the basic elements that characterized Big Data in technical (or technocratic) terms. Put differently, until now Big Data has been defined out of its context. As from now, we shall study Big Data not as an assemble of techniques, but as a unified neoliberal policy.

\section{Big Data and neoliberalism}

Big Data is a strand of the neoliberal project, whose aim is to improve the effectivization of surplus value and the implementation of new mechanisms that permit monitoring people.

Let us exemplify these ideas related to the use of Big Data in the porn industry. Pornhub, a porn website, "uses algorithms to create a highly curated, personalized site based on user's keyword search history, location, and even the time of day they log on" (Tarrant, 2016, 44). In other words, such an algorithmic business strategy permits as the elaboration of users' profiles as well the development of ameliorated marketing strategies that assure a highly profitable business. Thus, by profiling the user through his/her clickstream, Pornhub is able to "control" the sexual instinct of such users so as to both manipulate them and, in tandem, sell more porno commodities. Ergo, the user is not just tamed, but also alienated so that the user itself is able to effectivize the surplus value that lies in such commodities -the process of surveillance then becomes capital. ${ }^{5}$

What is more, it is worth indicating that algorithms conceal "the presence (or lack of) intentionality" (Lee, 2018, 5), with which "people will react to algorithmic decisions less emotionally because people [wrongly] attribute less agency and intentionality to algorithms" (Lee, $2018,5)$. On the contrary, algorithms are plenty of agency and intentionality. Both the agency and

\footnotetext{
${ }^{4}$ For example, an Exabyte (Eb) is equivalent to $10^{18}$ _ "a million terabytes" (Holmes, 2017).

5 "That is the key point: the audacious yet largely disguised corporate attempt to incorporate all of life, whether or not conceived by those doing it as "production," into an expanded process for the generation of surplus value. The extraction of data from bodies, things, and systems create new possibilities for managing everything" (Couldry and Mejias, 2018, 8).
} 
intentionality of algorithms must be sought in the context of the 1970 crisis $^{6}$-a terminal and systemic crisis.

Such agency and intentionality belong to the neoliberal project implemented by the bourgeoisie, which wants "the restoration of capitalist profitability and stable capital accumulation" (Humphrys, 2019, 10). Clearly, as we have seen with the example of Pornhub, there is an explicit intention that is the survival of the bourgeoisie at all cost. In this way, the bourgeoisie through the digital surveillance of people has been able to generate and accumulate large amounts of capital, while such a social class hides its intentionality under numbers (algorithms) that seem to be neutral tools. However, it is plain that algorithms have some implications:

numbers are never innocent, speaking for themselves, but always come marked by prior theorization: they are theory laden. Numbers do not speak for themselves but speak only for the assumptions that they embody. Numbers emerge only from particular social institutions, arrangements and organizations mobilised by power, political agendas and vested interests (Barnes, 2013, 300).

Algorithms admit of the violation of the rule of law, a neoliberal principle used to conceal the manipulation of the state apparatus in favour of the bourgeois interests. ${ }^{7}$ Evidently, neoliberalism is "a hegemonic state-centred project to restore accumulation after the 1970s economic crisis" (Humphrys, 2019, 8; emphasis added) -the State is not neutral, it is really a class instrument of domination and exploitation. ${ }^{8}$ Algorithms are no more than the power of the bourgeoisie disguised as an objective and neutral instrument -algorithms are technocratic weapons. ${ }^{9}$

On the other hand, while it is true that the economic is fundamental to the development of big data policies, the fact is that it is also essential, for the state-centered neoliberal project, to conquer the everyday life as a social space of capitalist reproduction. Thus, the conquest of everyday life through Big Data is especially reached by the processing of semi-structured data, which possesses information on the daily life of people -in this context, "natural language processing is the most relevant one" (Torra et al., 2019, 12). In fact, the access to the communication reached through natural language opens the door of the most private components of our quotidian existence -the perfect soil to sow the seeds of neoliberal fascism. ${ }^{10}$ It is therefore not surprising that algorithms have to be presented as something beyond good and evil, insofar as they must be represented by the acolytes of the bourgeoisie as something with no agency.

In addition, the big data colonization of the quotidian has implied an emphasis upon the emotional insofar as "[the bourgeois] Social order is in large part emotionally conditioned" (Srbljinović and Božić, 2014, 152). One instance of this process could be the emoji code so long as "emoji usage entails emotivity (consciously or unconsciously) (...) defined as the use of discourse structures (words, intonations, phrasings, etc.) to portray one's state of mind" (Danesi, 2017, 21). That is to say, the emoji code permits synthetizing distinct emotions through the image that interculturally represents a determinate emotion -an emotion-centered fascist strategy.

Apart from this, the emoji code is a part of biopower (Stark and Crawford, 2015) so long as, with the implementation of such a code, "the body becomes an object of knowledge to be monitored, coerced, and controlled in increasingly complex ways" (Cohen, 2016, 88) in order to "reinforce existing regimes of inequality and exploitation" (Stark and Crawford, 2015, 8). Indeed, provided that "there is a biological basis of emotions" (Turner, 2009, 341) that the neoliberal State can manipulate, so our affects will be manipulated, studied, socialized, and monetized (Stark and

\footnotetext{
${ }^{6}$ Couldry and Mejias (2018) study the big data phenomenon in terms of colonialism, which is correct but insufficient as long as they have forgotten the fundamental role played by the economic crisis that begins in the $1970 \mathrm{~s}$.

7 "Capitalism, neoliberalism and fascism are (...) fuzzy and even self-contradictory" (Micocci and Di Mario, 2018, 2).

${ }^{8}$ Of course, neoliberalism is a systematic class genocide (Alfaro-Vargas, 2019) so long as the neoliberal policies does only generate inequality, e.g. fifty percent of the world population solely possesses $0.2 \%$ of the world's riches (Achtnich, 2018) -millions of people are right now dying!

${ }^{9}$ In this way, Couldry and Mejias affirms that the big data phenomenon through algorithms "categorizes subjects and builds societies toward total algorithmic control" $(2018,11)$.

10 "Indeed, the best interpreter and manager of the spirit of 'capitalism as we know it' today is fascism in all its different brands" (Micocci and Di Mario, 2018, ix).
} 
Crawford, 2015) by the ruling class -this exemplifies the hidden intentionality of the bourgeoisie again.

Furthermore, clearly, such is the degree of emotionalization given by the use of the emoji code that it is difficult to disregard the idea that, under such an "innocent" code, lies a political project. The emoji commodification of affects is then fundamental to comprehending not only the reaching of Big Data as a capital-related and neoliberal policy, but the degree of alienation suffered by people in our digital age as well. In this era, people have been socialized to feel, not to think! So far what is completely evident is that the algorithmization of big data processing involves as the reification of our everyday life as well an enhancement of the circulation/reproduction of capital. Nevertheless, there is another salient consequence of the implementation of Big Data; i.e., the structuration of a big data onto-epistemology linked to set theory.

\section{The big data onto-epistemology}

Inasmuch as "Set theory (...) is general enough to deal with data analysis and problem solving" (Shu, 2016, 4), Big Data is a set-theoretic system of data processing; hence, "Extending set theory, probability-measured set, metric space, and topological space are often used in big data analysis" (Shu, 2016, 2) so as to compress reality into algorithms, not to explicate such reality (Danesi, 2017). In a post-postmodern context, Big Data is one more manifestation of a trend into a neoliberal academia that pretends "to measure almost all phenomena" (Fraser and Taylor, 2016, 13; emphasis added).

However, it is here necessary to explain the features associated with set theory so that we are able to discern the true linkage between both Big Data and such mathematical theory. Set theory is an ensemble of axioms, from which it is possible to deduce the existence of different sets. Thus, the axiom of foundation (or existence) affirms that "there is a set (and this is the void set)" (Gironi, 2015, 24) and, as long as "The empty set $\varnothing$ [the void set] is the subset of every set" (Burhanuddin, 2015, 46), the empty set marks the complete onto-epistemological structure of set theory. ${ }^{11}$

In general terms, set theory functions as an ordering instrument, given that it allows structuring all kind of sets that are legitimated by the all-encompassing presence of the empty set. By settheorizing reality, one might supposedly build whatever one wants; that is, one can define the extensionality (the assemble of elements of a set) that one requires at the moment in that if one establishes the set $A$ (containing the following components: \{a, quantum mechanics, tree\}), then the empty set, which is also the subset of the set $A,{ }^{12}$ would acquire an intensional function, since it would permit legitimating any possible extensionality. In other words, if the empty set exists, then it cannot be a part of a set including non-existing elements due to the logical principle of the excluded middle ( $A$ is $A$ or not $A$, but never both of them at the same time). Therefore, in a determinate set, it is not possible to have non-existing elements combined with existing ones.

Nevertheless, there is still an enormous problem: the empty set involves a contradiction -a paradox. The empty set is, of course, the set from which derives every set and, in tandem, the subset of every set (Burhanuddin, 2015); ergo, there is a vicious circle that annihilates set theory. In attempting to solve such a paradox, some theorists have elaborated the idea of defining "a set as an extension, rather than an intension" (Moore, 1978, 325); nonetheless, this implies that the only important is then the elements of a set rather than the rational and material principle that groups the components of such a set. What is really operating here is the eidetic law of dependence understood as some kind of formula that sets up the following: "quality $\rightarrow$ extension" (Petitot, 1994, 391), from which it is believed possible to generate an extension dependent upon a volitional act that would establish some type of quality. In other words, it is presumed that an intentional act can function as an intensionalizing process that admits of the creation of an extensional object;

\footnotetext{
${ }^{11}$ The reader can also consult, in relation to the onto-epistemology of set theory, Alfaro-Vargas (2019), especially the chapter one titled "The Dialectics of Totality and Set-theoretic Mere-topology".

${ }^{12}$ The set $A$ then contains the following components: a, quantum mechanics, tree, $\left.\varnothing\right\}$; that is, the empty set is also a component of $A$.
} 
i.e., it is assumed that the general structure of the intentionality ${ }^{13}$ can construct the extensional object. In consequence, set theory is the manifestation of a vulgar philosophical idealism -its most solipsist and nihilistic expression.

There are, indeed, many euphemistic nomenclatures to rename set theory; to wit: complexity theory, self-organization theory, emergentism, and so on. In this context, clearly, Big Data "is compression (into formulas and equations) that characterizes complexity" (Danesi, 2017, 183); that means, Big Data is a complex phenomenon that instrumentalizes data-sets through the construction of fuzzy sets (see Torra et al., 2019), which are made up of the elements and relationships that defined such sets (Castellani and Hafferty, 2009; Cilliers, 1998). ${ }^{14}$ In so doing, Big Data sets up models, ${ }^{15}$ which cannot "describe the entire dataset" (Veltri, 2017, 3) as far as Big Data tends to create descriptions of reality, with which it must be recognized "the limitations of the positivity of its discourse" (Iliadis and Russo, 2016, 2); i.e., Big Data is tied to a positivist conception of Being whose main characteristic is to define Being not only in terms of the logical principle of identity $(A=A)$, but in terms of an unchanging worldview (Weltanschanung) of reality as well. Put differently, not only is there no social change, but also there is sanctification of the status quo -an ideologization of the bourgeois world.

The onto-epistemological positivization of reality through Big Data is a mechanism that contradicts one of the imperatives of the complex conception that stems from the implementation of set theory, viz., the fact is here that the reality that had been quantized is now understood in Newtonian terms; that is, reality is comprehended as a notion from whence time and space are separated, thereby contradicting the anti-positivist position that defines complexity theory (Byrne, 1998) and the like. In fact, it is high time for us to figure out that the big data positivization of reality implies a worldview characterized as something changing and unchanging in tandem, which is quite impossible as long as this violates the logical principle of the excluded middle, due to the fact that $A$ and non- $A$ cannot exist at the same time -this absolutely annihilates the big data settheorization of reality.

However, there is another consequence of such big data onto-epistemology, owing to the fact that the unique manner of conceiving reality as something unchanging (related to the logical principle of identity) is to construct a distorted/distorting temporality; i.e., it is artificially produced a temporality defined as an eternal repetition of the past:

Descriptive analytics is about describing what happened in the past, predictive analytics is about predicting what will happen in the future based on the assumption that what happened in the past will happen in the same or a similar way in the future, and prescriptive analytics is about how to be better prepared for the future based on our prediction of the future needs (Xu and Duan, 2018, 6-7).

In this manner, the principle of entropy (the second law of thermodynamics) that guides the development of quantum theory is used to engender the quite wrong idea that capitalism is a nonentropic system and, therefore, eternal. ${ }^{16}$ Next, Big Data is only a bourgeois ideology, since it distorts both our comprehension of reality and our capacity of social transformation.

On the other hand, evidently, "Algorithms and data [as a strand of the neoliberal project] are neither neutral nor impartial" (Aragona and de Rosa, 2018, 5) inasmuch as both algorithms and data respond to the necessity of a ruling class that seeks to survive at any cost. Algorithms and data are, therefore, the best manifestation of a technological/technocratic fascism (Alfaro-Vargas,

\footnotetext{
13 This structure is synthetized in the following manner: "act (content) $\rightarrow$ [object]" (Tieszen, 1999, 444).

14 "But the size of these increasingly large sets of data cannot alone provide a definition for the term 'big data'-we must include complexity in any definition," explains Holmes (2017).

15 In respect of the notion of model, Lefebvre states the following critique: "The most important and interesting aspect is undoubtedly the methodology of models. This is claimed to be absolutely scientific. The expert proceeds by constructing a model, putting the "lived" into parentheses, and extracting certain variables (as few as possible) from the chaos of this "lived": he then reassembles these in such a way as to constitute a coherence, which he substitutes for the lived's incoherence and lack of cohesion" (1976, 54). Hence, models are an absurd reductionism that does not explain any reality.

${ }_{16}$ To this respect, see: (Konings, 2018), (Harvey, 2018) and Žižek (2019), who have developed such idea so as to legitimize capitalism. Even, it is worth mentioning that Harvey (2018) disguises his approach as a Marxist one, but it is really anti-Marxist -it is anti-dialectical. In fact, Harvey (2018) and Žižek (2019) are a manifestation of far-right Marxism (Alfaro-Vargas, 2019).
} 
2019) insofar as "Algorithms [and data] become alternatives [not just] to laws, regulations, and social processes generally (...) [but also to] human judgment" (Deighton, 2018, 4-5). Otherwise, the quotidian has totally been coopted by the interests of the bourgeoisie.

\section{Conclusion}

The phenomenon of Big Data must be understood as a mechanism of social control as well as a process that seeks to enhance, in terms of accumulation, the circulation/reproduction of capital.

On the one hand, Big Data are an assemble of techniques (velocity, veracity, etc.) whose aims are both to process a large amount of structured, semi-structured, and unstructured data so as to obtain information that can be used for developing business strategies and to monitor users' profiles -and, in fact, the manipulation of such users. In this sense, the use of algorithms is fundamental to the implementation of such data science.

On the other hand, as its dialectical pair, Big Data is a neoliberal policy that utilizes the big data techniques and its algorithms to assure both the supposed eternalization of capitalism and the survival of the bourgeoisie through an ideological distortion of reality, where it is established an onto-epistemological discourse that affirms a worldview comprehended as an eternal repetition of the past.

The onto-epistemology of Big Data is clearly defined in set-theoretic terms in order to conceal the intentionality of the bourgeoisie, through a group of "epistemic" strategies that solipsistically and nihilistically elaborated the wrong idea that capitalism and the bourgeoisie (as a ruling class) are eternal. Thus, by using algorithms, the intentionality of the bourgeoisie is reduced to the intensionality of the empty set and vice versa - Big Data is not only a vulgar idealism, but a technocratic/technological fascism as well. Big Data, a part of the neoliberal policies, is to be sublated. For this reason, it is imperative that we be able to develop revolutionary actions to counteract the effects produced by Big Data: "we must recover a site of resistance which confronts the new and distinctive appropriations of twenty-first-century capitalism, as practices of data processing are played out across a global terrain of differentiated exploitation" (Couldry and Mejias, 2018, 3).

\section{References}

Achtnich, Tilmann (reporter). (2018). Juego sin límites: las mentiras del libre comercio. Südwestrundfunk SWR/Deutsche Welle DW. Germany. Available at

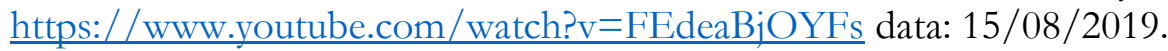

Alfaro-Vargas, Roy. (2019). La undécima tesis: dialéctica del fascismo neoliberal. Progreso Editorial. Costa Rica. Available at https://yadi.sk/i/YqiEpv XUITJww?fbclid=IwAR2nHSY1DigWRaw3PzhMwnMwZpy hra11vW3whl5dn5-IpI4NprW2PcACy0k data: 15/08/2019.

Aragona, Biagio \& de Rosa, Rossana. (2018). Big Data in policy making. Mathematical Population Studies. UK and USA (Pp.1-7). DOI: $10.1080 / 08898480.2017 .1418113$

Barnes, Trevor J. (2013). Big Data, little history. Dialogues in Human Geography. Vol. 3, No 3. UK (Pp. 297-302). DOI: $10.1177 / 2043820613514323$

Burhanuddin, Baki. (2015). Badiou's Being and Event and the Mathematics of Set Theory. Bloomsbury. UK and USA.

Byrne, David. (1998). Complexity Theory and the Social Sciences. An Introduction. Routledge. UK and USA.

Castellani, Brian \& Hafferty, Frederic William. (2009). Sociology and Complexity Science. A New Field of Inquiry. Springer. Germany.

Cilliers, Paul. (1998). Complexity and Postmodernism. Understanding Complex Systems. Routledge. UK and USA.

Cohen, Bruce M.Z. (2016). Psychiatric Hegemony: A Marxist Theory of Mental Illness. Palgrave Macmillan. UK. DOI: $\underline{10.1057 / 978-1-137-46051-6}$ 
Couldry, Nick and Mejias, Ulises A. (2018). Data Colonialism: Rethinking Big Data's Relation to the Contemporary Subject. Television \& New Media. UK (Pp. 1-14). DOI: $10.1177 / 1527476418796632$

Danesi, Marcel. (2017). The Semiotics of Emoji. Bloomsbury. UK and USA.

Deighton, John. (2018). Big data. Consumption Markets \& Culture. UK (Pp. 1-6). DOI: $10.1080 / 10253866.2017 .1422902$

Fraser, Heather \& Taylor, Nik. (2016). The University Goes to Market: The Infiltration of Neoliberalism. In Fraser, Heather and Taylor, Nik. Neoliberalization, Universities and the Public Intellectual: Species, Gender and Class and the Production of Knowledge. Palgrave Macmillan. UK. DOI: 10.1057/978-1-137-57909-6 1

Gironi, Fabio. (2015). Naturalising Badiou. Mathematical Ontology and Structural Realism. Palgrave Macmillan. UK and USA.

Harvey, David. (2018). Marx, Capital and the Madness of Economic Reason. Oxford University Press. USA.

Holmes, Dawn E. (2017). Big Data. A Very Short Introduction. Oxford University Press. UK. Humphrys, Elizabeth. (2019). Introduction. In Humphrys, Elizabeth. How Labour Built Neoliberalism: Australia's Accord, the Labour Movement and the Neoliberal Project. Brill. The Netherlands and USA. DOI: $10.1163 / 9789004383463002$

Iliadis, Andrew \& Russo, Federica. (2016). Critical data studies: An introduction. Big Data \& Society. UK (Pp. 1-17). DOI: $10.1177 / 2053951716674238$

Kitchin, Rob \& McArdle, Gavin. (2016). What makes Big Data, Big Data? Exploring the Ontological characteristics of 26 datasets. Big Data \& Society. UK (Pp. 1-10). DOI: $10.1177 / 2053951716631130$

Kitchin, Rob. (2014). Big Data, new epistemologies and paradigm shifts. Big Data \& Society. UK (Pp. 1-12). DOI: $10.1177 / 2053951714528481$

Konings, Martijn. (2018). Capital and Time: For a New Critique of Neoliberal Reason. Stanford University Press. USA.

Lee, Min Kyung. (2018). Understanding perception of algorithmic decisions: Fairness, trust, and emotion in response to algorithmic management. Big Data \& Society. UK (Pp. 1-16). DOI: $10.1177 / 2053951718756684$

Lefebvre, Henri. (1976). The Survival of Capitalism: Reproduction of the Relations of Production. St. Martin's Press. USA.

Micocci, Andrea \& Di Mario, Flavia. (2018). The Fascist Nature of Neoliberalism. Routledge. UK and USA.

Moore, Gregory H. (1978). The Origins of Zermelo's Axiomatization of Set Theory. Journal of Philosophical Logic. Vol. 7, No 1. Germany (Pp. 307-329).

Petitot, Jean. (1994). Phenomenology of Perception, Qualitative Physics and Sheaf Mereology. In Casati, Roberto; Smith, Barry, and White, Graham (eds.). Philosophy and the Cognitive Sciences. Hölder-Pichler-Tempsky. Austria.

Shu, Hong. (2016). Big data analytics: six techniques. Geo-spatial Information Science. USA and UK (Pp. 1-10). DOI: 10.1080/10095020. 2016.1182307

Srbljinović, Armano \& Božić, Jasmina. (2014). Implications of the Sociology of Emotions for the Restoration of Social Order. Emotion Review. Vol 6 No 2. UK (Pp. 152-159). DOI: $\underline{10.1177 / 1754073913503371}$

Stark, Luke \& Crawford, Kate. (2015). The Conservatism of Emoji: Work, Affect, and Communication. Social Media + Society. UK (Pp. 1-11). DOI: $10.1177 / 2056305115604853$

Tarrant, Shira. (2016). The Pornography Industry: What Everyone Needs to Know. Oxford University Press. USA.

Tieszen, Richard. (1999). Mathematics. In Smith, Barry and Smith, David Woodruff (eds.). The Cambridge Companion to Husserl. Cambridge University Press. USA. 
Torra, Vicenç; Karlsson, Alexander; Steinhauer, H. Joe, and Berglund, Stefan. (2019). Artificial Intelligence. In Said, Alan and Torra, Vicenç (eds.). Data Science in Practice, Studies in Big Data 46. Springer. Switzerland. DOI: 10.1007/978-3-319-97556-6 2

Turner, Jonathan H. (2009). The Sociology of Emotions: Basic Theoretical Arguments. Emotion Review. Vol. 1, No 4. UK (Pp. 340-354). DOI: $10.1177 / 1754073909338305$

Veltri, Giuseppe. (2017). Big Data is not only about data: The two cultures of modelling. Big Data \& Society. UK (Pp. 1-6). DOI: $10.1177 / 2053951717703997$

Xu, Li Da \& Duan, Lian. (2018). Big data for cyber physical systems in industry 4.0: a survey. Enterprise Information Systems. USA and UK (Pp. 1-22). DOI: $10.1080 / 17517575.2018 .1442934$

Žižek, Slavoj. (2019). The Relevance of the Communist Manifesto. Polity. UK and USA. 